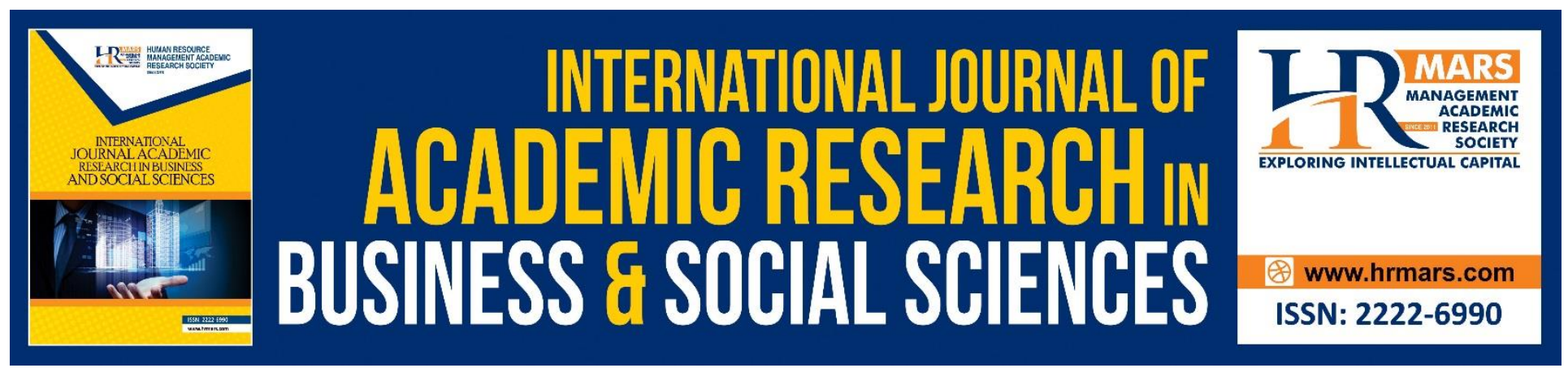

\title{
Mudarabah Contract in Islamic Cooperative Institutions: A Conceptual Study
}

\section{Norsilawati Mohd Hassan, Nur Azura Sanusi}

To Link this Article: http://dx.doi.org/10.6007/IJARBSS/v9-i3/5657

DOI: $\quad 10.6007 /$ IJARBSS/v9-i3/5657

Received: 15 Jan 2019, Revised: 24 Feb 2019, Accepted: 03 March 2019

Published Online: 08 March 2019

In-Text Citation: (Hassan \& Sanusi, 2019)

To Cite this Article: Hassan, N. M., \& Sanusi, N. A. (2019). Mudarabah Contract in Islamic Cooperative Institutions: A Conceptual Study. International Journal of Academic Research in Business and Social Sciences, 9(2), 994-1003.

Copyright: (C) 2019 The Author(s)

Published by Human Resource Management Academic Research Society (www.hrmars.com)

This article is published under the Creative Commons Attribution (CC BY 4.0) license. Anyone may reproduce, distribute, translate and create derivative works of this article (for both commercial and non-commercial purposes), subject to full attribution to the original publication and authors. The full terms of this license may be seen at: http://creativecommons.org/licences/by/4.0/legalcode

Vol. 9, No. 3, 2019, Pg. 994 - 1003

http://hrmars.com/index.php/pages/detail/IJARBSS

JOURNAL HOMEPAGE

Full Terms \& Conditions of access and use can be found at http://hrmars.com/index.php/pages/detail/publication-ethics 


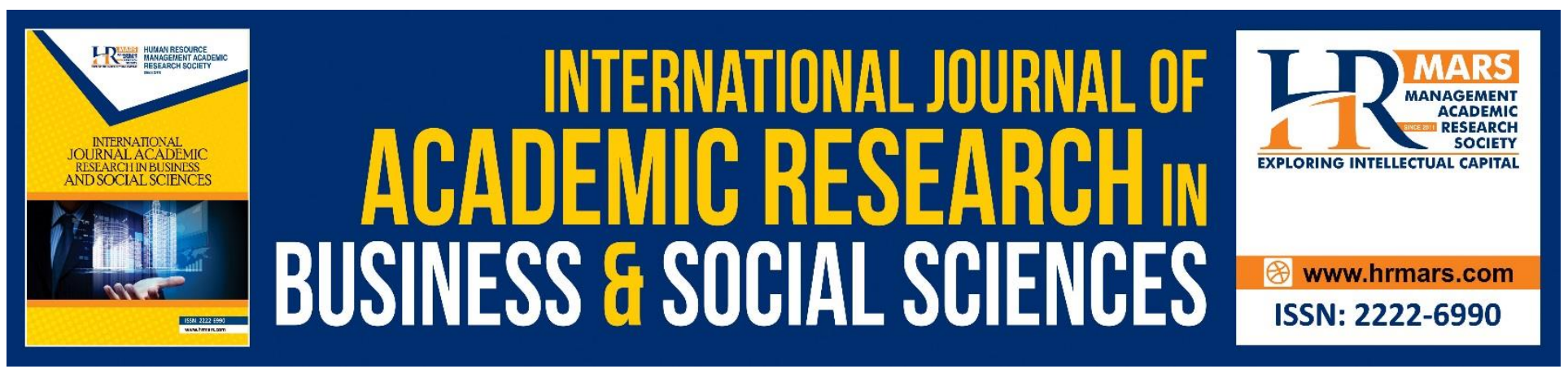

\title{
Mudarabah Contract in Islamic Cooperative Institutions: A Conceptual Study
}

\author{
Norsilawati Mohd Hassan ${ }^{1,2}$, Nur Azura Sanusi ${ }^{3}$ \\ ${ }^{1}$ Faculty of Business and Management, University Technology MARA Cawangan Kelantan, Malaysia. \\ E-mail: norsi963@kelantan.uitm.edu.my \\ ${ }^{2} \mathrm{PhD}$ Student, ${ }^{3}$ Senior Lecturer \\ Universiti Malaysia Terengganu, Malaysia.
}

\begin{abstract}
There is a need to uphold integrity among the management in order to strengthen Islamic cooperative institutions in Malaysia. This paper aims to observe the development of mudarabah contract and practice in Islamic Cooperative Institutions (ICI) in Malaysia. Next, it also aims to theoretically establish mudarabah contract in Islamic cooperative institution model in Malaysia that employs IIE-process (shuratic process). This study is a qualitative-based research. It uses literature reviews, documents and content analysis approach to document, understand and analyse the structure, process and practice of mudarabah contract in $\mathrm{ICl}$ in Malaysia. This study attempts to comprehensively examine the evolution of the mudarabah contract in ICI in Malaysia. After the introduction of the background problem, this paper will present the literature on Islamic Cooperative institutions in Malaysia, shuratic social learning process, reduce principal agent problems and uphold integrity. This study contributes in uphold integrity among the management in order to strengthen mudarabah contract of Islamic cooperative institutions in Malaysia.

Keywords: Mudarabah Contract, Islamic Cooperative Institutions, Shuratic Social Learning, Principal Agent, Uphold Integrity
\end{abstract}

\section{Introduction}

Malaysia, has emerged as an important leader country in the Islamic finance industry that aligned with Maqasid al-Shariah ${ }^{1}$ which aims to achieve just and equitable distribution of wealth among economic participants. With regards to the Islamic finance industry, a framework of mudarabah contract has been developed in $\mathrm{ICl}$ in Malaysia to overcome financial exclusion. A flexible and robust

\footnotetext{
${ }^{1}$ The concept of Maqasid Shariah provides a clear guidance and framework to the process of ijtihad in solving the issues conforming to the human interest while complying with the will of God.
} 
solution is needed to ensure that total Muslim's Commitment in keeping promises to Shariah (Islamic law) compliance.

This paper attempts to observe the development of shuratic social learning process of mudarabah contract in $\mathrm{ICl}$ in Malaysia from its inception until recently. It adopts the content analysis approach ${ }^{2}$ to examine the evolution of the mudarabah contract in $\mathrm{ICl}$ Malaysia. ${ }^{3}$ It also explains the development of dynamic setting as it becomes an important element in designing a contract.

\section{Issues and Challenges of Cooperatives in Malaysia}

Cooperatives are formed with the idea of mutual co-operation. Every cooperative movement is developed to render service to its members rather than to earn profit. ${ }^{4}$ However, the Malaysian cooperative movement faced many problems and challenges that need to be addressed by the cooperative themselves and the government. For many years, issues such as lack of capital, undertaking of conventional activities, weak structure, absence of good governance, lack of cooperation between cooperatives in the field of business, training, education and facilitating services, lack of managerial talent, lack of integrity among the management and the members in some cooperatives, are contributing to the inefficient performance of cooperatives in Malaysia (Mohamad, Othman, \& Mohamed, 2013).

In this study, the principal-agent problem due to asymmetric information arise due to in the problem of lack of integrity and accountability ${ }^{5}$ among the management that resulted in poor financial performance, mismanagement and non-compliance with the Cooperative Societies Act 1993. In furthermore, this in turn, results to the decrease in the ability of government, members and other stakeholders to monitor and regulate cooperative movements. Due to that, Malaysian Government has continuously putting efforts to improve the cooperative movement. ${ }^{6}$

\section{The Relationship between Cooperative Framework and Mudarabah Financing}

It is well known from the literature that an Islamic economy must be guided by interest-free instruments from the moral injunctions of Qur'an and Sunnah as these become the epistemological sources of Islamic law Shariah. Profit-sharing system such as mudarabah and can replace interestbased financial instruments. As respect to the Shariah, these make the criterion of pervasively participatory, cooperative and co-ordinated enterprise under mudarabah as a Shariah requirement with respect to Islamic joint venture (Choudhury, 2001).

However, there has seemed a serious obstacle for attaining cooperative participation in recognizing this goal through such instruments mudarabah due to the problems of imprecision and inequity. With this kind of sleeping partnership instrument, cooperative lose their capability of enhancing empowerment and entitlement, learning and participation among factors of production. In detail, there are some technical problems arises, first in failing to make the management practice responsive to cooperative participation among all business partners; second, in failing to introduce a

\footnotetext{
2 Double check

${ }^{3}$ Ini contra dengan Results of the study would include the modus operandi document of the key enablers of the best functions for Islamic cooperative institutions in Malaysia.

${ }^{4}$ non-banking institutions

${ }^{5}$ Stated in SKM report

${ }^{6}$ Motivation factor to conduct this study
} 
well determined method of mudarabah profit sharing in which value imputation of work effort would become a positive sharing measure along with wages and the shares of capital owners.

Yet no methodology has been developed to manifest the desired goal of cooperative participation in a technical understanding of the financing methods. Therefore, the objectives of socio-economic development that must promote entitlement, ownership and decision making by participation on the one hand, and on the other hand bring about financial risk diversification through re-negotiated contracts, are not found to emerge from these two financial instruments as they presently exist.

In order to transform these financial instruments to realize the goals of Shariah, extensively cooperative participation must be explicitly introduced in the mudarabah instruments. Generally, profit sharing (mudarabah) a form of partnership where one party provides the funds (rabbul maal) while the other (mudarib) provides expertise and management. The latter is referred to as the Mudarib. Any profits accrued are shared between the two parties on a pre- agreed basis, while loss is borne by the provider(s) of the capital (rabbul maal). However, in the case of negligence, all losses will be borne by the labor provider (mudarib). This is because the cooperative member (rabbul maal) acts as a silent partner in this venture that will cause a lesser degree of perceived information asymmetry (Sykuta \& Cook, 2001).

As mentioned above, asymmetric information problem may take place before and after a contract is signed causing adverse selection and moral hazard problems respectively. In the context of micro financing, the former problem may exist if the intended use of fund is different from that applied for. The latter problem arises when funds are used for purposes other than it was sanctioned for. In case of Islamic mode of financing used by IMFIs (i.e., bay[ mu'ajjal) this problem cannot arise in principle as instead of handing over cash, the good/asset is handed over to the beneficiary. As a result, diversion of funds to other purposes is not possible. In some cases, however, when cash is given out instead of good/asset the possibility of misuse of funds is there. Whereas Al-Fallah and Noble do not appear to have any problems of fund diversion to non-productive activities, Rescue has a few cases (12 percent) of fund diversion for consumption. Note that funds can be diverted mainly because cash is handed out instead of good/asset. Cash is often given out (not to the beneficiary directly but to a representative) due to the difficulties the IMFIs face in applying the Islamic mode of financing perfectly.(Ahmed, 2002)

As emphasized, innovation method can be implemented in order to reduce the problem of asymmetric information. In line with expectations for Islamic financial institutions to evaluate and manage the impact of their activities on the economy and society, the Bank is working with the industry and key stakeholders to develop a Corporate Value Intent (CVI) framework as a tool to assist Islamic banks to embrace and adopt value-based practices, premised on the objectives of Shariah. The framework aims to promote high quality disclosures by Islamic financial institutions on the intent, strategy and performance of their business, focusing specifically on how Islamic banks generate value for both shareholders and the wider community.

Therefore, to reduce the asymmetric information in mudarabah contract of Islamic cooperative institution, the very first perspective of Islamic methodology in socio-scientific systems, namely the shuratic process (equivalently Interactive, Integrative and Evolutionary process, IIE-

\footnotetext{
${ }^{7}$ Islamic Microfinance Institutions (IMFIs)
} 
process) provided to moderate principle-agent problem and increasing the returns of the contracting parties involved in this contract.

The shuratic process is the Qur'anic methodology of decision-making through dialogue (interaction), leading to agreement (integration), and further evolving to more of the same cycles of interrelationships (creative evolution). This characteristic of the knowledge-forming process is also referred to for Islamic socio-scientific systems as the interactive, integrative, and evolutionary process (IIE) of understanding the complexity of real world phenomena (Choudhury, 1998a). In addition, understanding the shuratic process to decision making is important to managers operating in Muslim countries. It is special in a cooperation system, namely, joint venture (musyarakah) and partnership (mudarabah). The shuratic process in its extended sense is now used to realize such an objective criterion of well-being for Islamic future. Consequently, market, sectorial and institutional linkages primarily with musharakah, murabaha (mark-up in foreign trade financing) and mudarabah instruments can evolve in reinforcing the direction of trade and development (Choudhury, 2016).

Therefore, a contract developed based on IIE-process (shuratic process) by the mudarabah contract is required for justice and fairness distribution of return. This IIE-process (shuratic process) then injects the epistemology into human inquiry through mutual interaction (ijtihad). The IIE-process (shuratic process) encourages the participants to work together freely and frankly, accuracy and honesty in business dealing. (Lewis, 2005), trust and reciprocity and shape the quality and quantity of an Islamic society's social interactions in providing the inputs and growth (Farooqi, 2006).

\section{The evolution of mudarabah contract in Islamic cooperative institutions in Malaysia}

To make mudarabah contract enforceable, shuratic social learning process is a comprehensive approach need to adopt by Islamic cooperative institutions in Malaysia that benefits both parties and reduces agency problems. Considering that, it is important that the practice of sound governance, leadership, accountability and transparency in the corporate sector are being implementing in the institution (Ramli \& Muhamed, 2013). In the early stage, cooperative movements in Malaysia began in 1911 with the aim of producing traditional loans and financing to members.

For Islamic financing, the traditional objective has been added value through the amendment of the Cooperative Act 1993 (Act 502) with the provision of "Islamic financing" was included in the act (Co-operative Societies Act 1993) (Act 502): 4). This provision provides that:

Space and opportunities for cooperatives in Malaysia for implementing Islamic financial principles including the principle of mudarabah in business operations on fund sourcing and funding. Hence implement the principle of mudarabah in the cooperative will be assessed and analyzed to determine its validity in order to ensure that they do not involve any element which is not approved by the religion of Islam ((Marzuki \& Haji, 2015).

In 1993, Suruhanjaya Koperasi Malaysia (SKM) introduced GP7: Guidelines on Islamic Financing by Cooperation. This guideline is issued under Section 86B and Subsection 51 (1) of the Act Co-operative 1993 (Act) to monitor and control cooperative giving credit facilities. Islamic financing is based on clear Shariah principles in meeting the financial needs of members, cooperatives and parties dealing with cooperatives, fairly, with integrity, fairness, trust and honest in besides ensuring a fair distribution of wealth. 
In 2009, the Shariah Advisory Council of Bank Negara Malaysia (BNM) decides that in a mudarabah transaction, mudarib is not allowed to guarantee the liability of another party dealing with it in a mudarabah-based transaction (Bank Negara Malaysia, 2010). ${ }^{8}$ Meanwhile, under SKM, the approach implemented can be categorized into 3 modus operandi as follows: ${ }^{9}$

\section{Model 1}

i. Cooperatives use internal resources to carry out credit activity.

ii. Management and handling of credit activities are managed entirely by cooperatives.

\section{Model 2}

i. The cooperative uses the bank's financing source channeled directly to the cooperative for activities credit.

ii. Management and handling of credit activities are managed entirely by cooperatives.

\section{Model 3}

i. The cooperative acts as an agent to an internal bank performing credit activities.

ii. The management and operation of credit activities are managed by bank.

iii. The cooperative only affords members eligibility for get financing.

iv. Financing money is not channeled to cooperative instead directly into the borrower's account.

v. Cooperatives only earn returns in the form of commissions.

The Cooperative Board was expected to deliver the following responsibilities:

a) the basis and the standard of grant funding are:

i. in line with business activities as stipulated in its by-laws; and

ii. in line with capital adequacy, management expertise and risk.

b) grant funding is in line with the objectives of business activities and the direction of the cooperative;

c) cooperative financing rules are presented for approval of general meetings. Financing arrangements should be reviewed from time to time and amended as necessary;

d) cooperatives at all times adopt good governance;

e) the responsible management of the cooperative has the ability to manage the activities of providing financing

f) the risk management process in financing activities is adequate;

g) an organized supervisory system is embodied in cooperative financing arrangements; and

h) the type of financing provided is not detrimental to the borrower and the promotion is not misleading of the borrower.

\footnotetext{
${ }^{8}$ Double check, keperluan sentence ini.

${ }^{9}$ Cooperatives are prohibited from carrying out Islamic financing activities at under Model 3.
} 


\section{Theoretical Framework}

There has been a growing literature focusing on the asymmetric information in $\mathrm{ICl}$ (Akhtaruddin \& Haron, 2010; Eng \& Mak, 2003; and Zouari \& Nabi, 2015) whereby financial institutions predictably suffer high transaction costs due to asymmetric information problems which naturally appear in the financial transactions. In addition, (Muhamad, 2008) found that obstacles remain when faced with offering the mudarabah product, such as moral hazard, asymmetric information and so forth. Significantly there has been no research conducted to specifically investigate these related attributes.

In the previous study conducted by (Mohamad et al., 2013), the principal-agent problem due to asymmetric information arise due to in the problem of lack of integrity among the management that resulted in poor financial performance, mismanagement and non-compliance with the Cooperative Societies Act 1993. In furthermore, this in turn, results to the decrease in the ability of government, members and other stakeholders to monitor and regulate cooperative movements. Considering that, Malaysian Government has continuously putting a paradigm shift to improve the cooperative movement.

Therefore, in effort to empower mudarabah contract and to lead in reduces agency problems, the role of IIE-process should be enhanced by Malaysian Government. Considering that it is important that the practice of sound governance, leadership, accountability and transparency in the corporate sector are being implementing in the institution (Ramli \& Muhamed, 2013).

\section{Theoretical model}

The aim of this part is to develop an optimal condition for mudarabah contract base on the principalagent model with the existence of asymmetric information in the Islamic cooperative/microfinance system. The asymmetric information problem occurs in this kind of contract due to the ambiguity problem of one agent to observe the action taken by another agent in managing their funds. This problem is more risk for mudarabah contract compared to other types of contract in Islamic cooperative/microfinance. Fundamentally, when the cooperative members (rabbul maal) invest their funds in mudarabah project, they can only observe their share of net profit that will be distributed by cooperative institutions (mudarib) at the end of the financial year or after the maturity period. The cooperative members (rabbul maal) act as a silent partner and not involve in the management of funds. As the cooperative institution (mudarib) have extra information regarding the investment compared to the cooperative members (rabbul maal), the cooperative institutions (mudarib) have an incentive to lie and insincerely reduce the declared profit. This problem is known as moral hazard problem.

Essentially, in this part, the researcher proposed to introduce IIE-process (shuratic process) as a new method to overcome the problem of asymmetric information. By IIE-process (shuratic process), both contracting parties able to develop a well-being systematic system in the institution through mutual and beneficial consultation in order to improve quality of to the stability and the existence of cooperatives as a viable and convincing entity. This procedure will able to reduce the asymmetric information between the contracting parties. Therefore, based on the above argument regarding shuratic process, this study will design two new optimization models for mudarabah contract. 


\section{The Mudarabah Model with Individual Learning}

In this study, it is adapt a mathematical model based on a two-tier profit-sharing (mudarabah) contract (Muda, Ismail, \& Shahimi, 2011). Basically, a two-tier mudarabah agreement in asymmetric information environment is from the liability and the asset side of Islamic cooperative, which the first tier is an agreement between cooperative members (rabbul maal) and cooperative institution (mudarib). In the mudarabah contract, cooperative members contribute funds to the cooperative institution. Meanwhile, in the second tier, cooperative institution acts as an entrepreneur by invest the funds received from cooperative members. Accrued profits from investing activities and financing will be shared among cooperative members and cooperative institution based on pre-agreed rates. However, loss will be borne by the members, except in cases where negligence is proved on the cooperative side in managing the funds (Suruhanjaya Koperasi Malaysia, 2009)

According to the Circular No. 1 of 2009, the cooperative is required to isolate Kumpulan Wang Rizab Statutori (KWRS) into a safe and secure liquid or liquid asset form such as fixed deposit or mudarabah investment to represent KWRS. For assets representing KWRS, the cooperative shall list the type and amount of investments made from the fund in the Notes to the Account including investments in the Cooperative Deposit Account [subsection 57 (1E) of the Act]. It should also be shown under the heading of Statutory Reserve Assets in the Current Assets section. Meanwhile, fixed deposits or Secured Mudarabah investments shall be shown under non-current assets (Koperasi, 2010).

In developing this mathematical model, there are some assumptions to simplify this study. Later, these assumptions will become the constraints in searching for optimization.

a) There are financing procedures has been established to ensure transparent governance and cooperative accountability.

b) This mudarabah contract is based on clear Shariah principles in meeting the financial needs of members, cooperatives and parties dealing with cooperatives, fairly, with integrity, fairness, trust and honest while ensuring equitable distribution of wealth and to avoid the asymmetric information problem.

c) The rate of return imposed should not burden the borrower. It should be based on the cost of funding and the cost of cooperative administration coupled with reasonable profits.

d) For cooperatives conducting Islamic financing activities, the return on financing depends on the agreement between the cooperative and the borrower.

e) Only takes into account or focus on investments in mudarabah contract.

f) Both parties agreed to use mudarabah contract. This means that cooperative institution will only provide the capital and hand over the responsibility on managing the fund in any appropriate project or investment to the entrepreneurs. Cooperative members will act as a silent partner and not involve in the management process.

\section{Conclusion}

Currently, it is important to maintain a good attention from governance of Shariah compliance in the Islamic Cooperative Institutions as these non-banking institutions able to reach their added value productivity to the current banking and finance products offered by the Islamic financial institutions. 
The role of shuratic process in the decision making process, especially at the time of contract design or renegotiation should be initiated by the Islamic cooperative as it can encourage the active participation by all the expert and involving parties in developing better decision using better information, knowledge, ideas and experiences that they have regarding the project venture.

From the theoretical model, the researcher observed that the implementation of the mudarabah contract able to boost the achievement of optimal net profit of the Islamic cooperative in the financing and investment activities, especially by adding up the shura algorithm.

\section{Acknowledgement}

We would like to give thanks to our team members for the hard work and cooperation through what initially seemed like an impossible journey. Finally, we also would like to express our appreciation to Bank Negara Malaysia officer for sharing important information in completing this study.

\section{Corresponding Author}

Nur Azura Sanusi is the corresponding author and can be contacted at: nurazura@umt.edu.my

\section{References}

Ahmed, H. (2002). Financing Microenterprises : An Analytical Study of Islamic Microfinance Institutions. Islamic Economic Studies, 9(2), 27-64. Retrieved from http://www.isdb.org/irj/go/km/docs/documents/IDBDevelopments/Internet/English/IRTI/CM/ downloads/IES_Articles/Vol 9-2..Habib Ahmed..Financing Microenterprises..dp.pdf

Akhtaruddin, M., \& Haron, H. (2010). Board ownership, audit committees' effectiveness, and corporate voluntary disclosures. Asian Review of Accounting, 18(3), 245-259. https://doi.org/10.1108/13217341011089649

Asutay, M. (2013). Islamic microfinance: Fulfilling social and developmental expectations. QFinance, 7. Retrieved from http://www.qfinance.com/financing-best-practice/islamic-microfinancefulfilling-social-and-developmental-expectations?page $=1$

Choudhury, M. A. (2001). Islamic Venture Capital: A Critical Examination. Journal of Economic Studies, 28(1), 14-33.

Choudhury, M. A. (2016). A prescriptive model of trade and development for the muslim world. Journal of Education and Social Sciences, 4, 65-75.

Eng, L. L., \& Mak, Y. T. (2003). Corporate governance and voluntary disclosure. Journal of Accounting and Public Policy, 22(4), 325-345. https://doi.org/10.1016/S0278-4254(03)00037-1

Farooqi, A. H. (2006). Islamic Social Capital and Networking. Emerald Journal, 22(4), 113-125. https://doi.org/10.1108/08288660610669400

Koperasi, S. (2010). GP23: garis panduan pelaporan penyata kewangan koperasi, 1-62.

Lewis, M. K. (2005). Islamic Corporate Governance. Review of Islamic Economics, 9(1), 5-29. https://doi.org/10.4337/9781783479825.00021

Malaysia, B. N. (2010). Resolusi Syariah dalam Kewangan Islam Edisi Kedua.

Marzuki, M., \& Haji, B. (2015). Pelaksanaan Prinsip Al-Mudarabah Di Koperasi Kolej Poly-Tech MARA Kuala Lumpur Berhad, 10(September), 529-538.

Mohamad, M., Othman, I. W., \& Mohamed, A. (2013). Accountability Issues and Challenges: The Scenario for Malaysian Cooperative Movement. International Journal of Economics and 
Management Engineering, 7(6), 1503-1508. https://doi.org/scholar.waset.org/1999.10/1437

Mohieldin, M., Iqbal, Z., Rostom, A., \& Fu, X. (2012). The Role of Islamic Finance in Enhancing Financial Inclusion in Organization of Islamic Cooperation (OIC) Countries. Islamic Economic Studies, 20(2), 55-120. https://doi.org/10.1596/1813-9450-5920

Muda, R. B., Ismail, A. G., \& Shahimi, S. (2011). Profit-Loss Sharing and Economic Value Added in Islamic Banking Model. Profit-Loss Sharing and Economic Value Added in Islamic Banking Model.

Muhamad, A. M. A. (2008). Islamic Finance for Micro and Medium. International Conference on "Inclusive Islamic Financial Sector Development: Enhancing Islamic Financial Services for Micro and Medium Sized Enterprises" Was, (February), 379. https://doi.org/10.1016/S00652776(08)60014-0

Ramli, N. M., \& Muhamed, N. A. (2013). Good Governance Framework for Corporate Waqf : Towards Accountability Enhancement. Proceedings Of World Universities' Islamic Philanthropy Conference 2013 Good.

Suruhanjaya Koperasi Malaysia. (2009). GP7: Garis Panduan Mengenai Pembiayaan Islam Oleh Koperasi, 51(1), 1-32.

Sykuta, M. E., \& Cook, M. L. (2001). A New Institutional Economics Approach to Contracts and Cooperatives (Vol. 83).

Zouari, Z., \& Nabi, M. S. (2013). Enhancing the Enforceability of Islamic Microfinance Contracts in OIC countries. 